\title{
BIOECONOMY: FERMENTED WASTE MANAGEMENT AND PECTINASES PURIFICATION FROM THERMOMYCESLANUGINOSUS
}

\author{
E.A. Makky*and Mashitah M. Yusoff \\ Faculty of Industrial Sciences and Technology, \\ Universiti Malaysia Pahang, 26300 Kuantan, Gambang, Pahang, Malaysia \\ *Email: essammakky@ump.edu.my \\ Phone: +6095492454; Fax: +6095492766
}

\begin{abstract}
Sugar-cane bagasse (SCB) is used for pectinases production from Thermomyceslanuginosus at $55^{\circ} \mathrm{C}$ under solid-state fermentation (SSF). The study aims to purify total PNL and PL enzymes produced from SCB as the sole carbon source at $55^{\circ} \mathrm{C}$ using microbial fermentation technology, and to evaluate the fermented bagasse residuals as fertilizer for the purpose of combatting soil desertification and then detect the amino acids content. The total PNL and PL enzymes were purified and showed two identical peaks, each representing one enzyme. Biotechnological applications of fermented bagasse obtained at $55^{\circ} \mathrm{C}$, used as biofertilizer at different concentrations, were cultivated with Zea mays for 30 days to indicate the growth on sandy soil, and induced plant growth which gives an indication of applying the present biofertilizer in reclaimed sandy soils. Only 13 amino acids were detected and were obviously glycine/histidine-containing enzymes. It is apparent that the fermented bagasse successfully improved the sandy soil as biofertilizer and total PNL and PL enzymes were accurately purified at thermophilic conditions under SSF.
\end{abstract}

Keywords: Pectin lyase; pectate lyase; Thermomyceslanuginosus; biofertilizer; solidstate fermentation.

\section{INTRODUCTION}

Researchers all over the world today are focusing on ways of utilizing either industrial or agricultural wastes as a source of raw materials for industry. Utilization of these wastes would not only be economical, but also result in foreign exchange earnings and environmental pollution control [1]. The enzyme preparations used in the food industry are of fungal origin because fungi are potent producers of pectic enzymes and the optimal $\mathrm{pH}$ of the fungal enzymes is very close to the $\mathrm{pH}$ of many fruit juices, in the range of $\mathrm{pH} 3-5.5$. Such preparations are not suitable for the production of vegetable purees or other preparations in which $\mathrm{pH}$ values are close to neutral. Therefore, commercial pectinase production is still dominated mainly by Aspergillusniger strains. But these enzymes suffer from limitations like low temperature stability. Solid state fermentation (SSF) has tremendous potential for the production of enzymes. It is of special interest in processes where the crude fermented product may be used directly as the enzyme source. This system offers numerous advantages over the submerged fermentation $(\mathrm{SmF})$ system, including high volumetric productivity, a higher concentration of the products, less effluent generation, requirement for simple fermentation equipments, etc. [2]. Pectinases are a group of enzymes that are involved 
in degradation of pectin and include various enzymes classified into various classes and subclasses depending on the substrate specificity and mode of action, for example, methyl deesterases, hydrolases, and lyases. According to the cleavage site, pectinases are divided into three groups: (i) hydrolases consisting of polygalacturonase, PG (EC 3.2.1.15); (ii) lyase/trans-eliminases comprising pectin lyase, PNL (EC 4.2.2.10), and pectatelyase, PL (EC 4.2.2.2); (iii) pectin esterase, PE (EC 3.1.1.11) [3]. Pectinases are widely distributed in higher plants and microorganisms. They are today one of the upcoming enzymes of the commercial sector. It has been estimated that microbial pectinases account for $25 \%$ of the global food enzymes sales. Among industrial applications of pectinases are using these enzymes as an animal feed supplementation [4].Sugar cane bagasse is one of the main by-products generated during production of first generation bioethanol and is also recognized as a very promising feedstock for cellulosic ethanol or second generation bioethanol due to the high carbohydrate content that remains in the fibre $[5,6]$. However, the low yield from the conversion into fermentable sugars is a challenge because the recalcitrance of lignocellulose limits the access of cellulases to the cellulose chains [7-9]. Solid-state fermentation involves the growth of microorganisms on moist substrate. It offers advantages over liquid fermentation, as there is higher productivity, reduced energy requirements, low capital investment, low wastewater output, a higher concentration of metabolites obtained and a low downstream processing cost [10].In this study, we report the purification of total PNL and PL enzymes, then evaluate the fermented bagasse residuals as fertilizer for the purpose of combatting soil desertification and then detect the amino acids contained in these enzymes.

\section{MATERIALS AND METHODS}

\section{Growth Medium}

The medium used for fungal induction and growth under SSF conditions contained basically $5 \mathrm{~g}$ of the dried and ground sugar cane bagasse (SCB) supplemented with only $25 \mathrm{ml}$ of mineral salts starch-nitrate yeast-extract medium, which consisted of $(\mathrm{g} / \mathrm{l}, \mathrm{w} / \mathrm{v})$ : $\mathrm{NaNO}_{3}, 2 ; \mathrm{K}_{2} \mathrm{HPO}_{4}, 1 ; \mathrm{MgSO}_{4} .7 \mathrm{H}_{2} \mathrm{O}, 0.5 ; \mathrm{KCl}, 0.5$; yeast-extract, 2 . The mineral salts (MS) ingredients were dissolved and completed up to one litre of tap water. Only $50 \mathrm{ml}$ aliquots were added to the applied natural substrate, then autoclaved at 1.5 atmospheric pressure for $20 \mathrm{~min}$ and inoculated with the fungal growth discs, and the growth was estimated by making a suspension per each disc.

\section{Pectinases Assay and Purification}

Total PNL and PL productivity in cell free filtrate (CFF) was assayed by quantification of reducing sugars using 3,5-dinitrosalicylic acid (DNS) reagent [10]. The reaction mixtures of pectinases enzymes assay are described in detail in Makky [11]. During the course of pectinases purification, enzymes were produced by T.lanuginosus at $55^{\circ} \mathrm{C}$ incubation temperature due to their growth on the dried SCB at optimal static natural substrate under SSF conditions. Only $4 \mathrm{~g}$ of natural substrate SCB per flask of $2000 \mathrm{ml}$ capacity were used and supplemented by $50 \mathrm{ml}$ of MS-1 consisting of $(\mathrm{g} / \mathrm{l} ; \mathrm{w} / \mathrm{v}): \mathrm{NaNO}_{3}$, $2.0 ; \mathrm{K}_{2} \mathrm{HPO}_{4}, 1.0 ; \mathrm{MgSO}_{4} .7 \mathrm{H}_{2} \mathrm{O}, 0.5 ; \mathrm{KCl}, 0.5$; yeast extract, 2.0 in addition to $\mathrm{KNO}_{3}$, ribose and folic acid adjusted at $\mathrm{pH} 6.2$, and incubated for 5 days at $55^{\circ} \mathrm{C}$. At the end of the incubation period, the $\mathrm{CFF}$ was saturated with ammonium sulphate, and then 
centrifuged at 15,000 rpm for $15 \mathrm{~min}$ and the pellet was resuspended in Tris- $\mathrm{HCl} \mathrm{pH} 8.0$ to determine both the enzyme activity and protein content according to Lowry et al. [12]. The calculation of the solid ammonium sulphate to be added at any concentration was obtained by the chart in Gomori [13], as mentioned by Dixon and Webb [14]. The obtained enzyme preparations were dialyzed against sucrose $30 \%(\mathrm{w} / \mathrm{v})$, and this dialyzed enzyme $(1 \mathrm{ml})$ was subsequently loaded on a gel filtration using a $12.5 \times 1.7 \mathrm{~cm}$

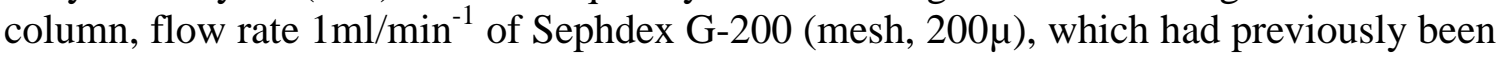
equilibrated with the same buffer of enzyme activity, then eluted.

\section{Characterizationof Purified Pectinases Activity}

The relation of time progression to the reaction mixture of pectinases was studied. The identical reaction mixture was incubated for $10,20,30,40,50$, and 60 minutes at $55^{\circ} \mathrm{C}$ for purified enzyme. At the end of the different incubation times, pectinase activity was determined after each factor. To study the relation of different $\mathrm{pH}$ values, the purified total PNL and PL enzymes were incubated at $\mathrm{pH}$ values 7.2, 8.0, and 9.0 using $(0.05 \mathrm{M})$ Tris- $\mathrm{HCl}$ buffer for $10 \mathrm{~min}$. The effect of the different enzyme concentrations was also studied. Different concentrations were prepared from purified PNL and PL enzymes in the range of 50-300 $\mu \mathrm{l}$. The reaction mixture was incubated for $20 \mathrm{~min}$ at $37^{\circ} \mathrm{C}$. For thermal stability of pectinases activity, the experiment was designed to determine the range of temperature within which the purified pectinases enzymes maintained their activities by incubating the purified enzymes for 3 hours at different temperatures, viz: $10,20,30,40,50,60,70$ and $80^{\circ} \mathrm{C}$. At the end of treatment, the replicate tubes were cooled and assayed for each purified enzyme to determine the retained enzyme activity. The relation of different substrate concentrations (pectin) was determined. The pectin was applied at different concentrations (w/v,\%): 0.1, 0.2, 0.4, 0.8 and 1.0 of purified total PNL and PL enzymes [15].

\section{Biotechnological Application of Fermented Biomass}

The application was carried out after the production of enzymes under the optimum SSF conditions; the wastes of fermented bagasse [16] were dried and used for the growth of Zea mays as compost at different concentrations, viz: 0.0. 0.5, 1.0, 1.5, 2.0, 2.5 and 3\% $(\mathrm{w} / \mathrm{w})$ in sandy soil to determine the ability of FB obtained from the production of pectinases enzymes to initiate the growth of Zea mays when cultivated in sandy soil for 30 days. The quantitative determination of chlorophyll was described according to Vernon and Seely [17]. The optical density of the extract was measured colorimetrically at two wavelengths (649 and $665 \mathrm{~nm}$ ). These are positions in the spectrum where maximum absorption by chlorophyll (a) and (b) occurs. The concentration of chlorophyll (a) and (b) and total chlorophyll in plant tissue were calculated by the following Eq. (1-3):

$$
\begin{array}{r}
\text { mg.Chl. } \frac{a}{g m} . \text { Tissue }=11.63(\text { A665) }-2.39 \text { (A649) } \\
\text { mg.Chl. } \frac{b}{g m} \cdot \text { Tissue }=20.11 \text { (A649) }-2.39 \text { (A665) } \\
\text { mg.Chl } \frac{a+b}{g m} . \text { Tissue }=6.45(\text { A665) }+17.72 \text { (A649) }
\end{array}
$$

where ' $A$ ' denotes the optical density reading. 


\section{Amino Acid Analysis}

Amino acid analytical data of the purified pectinases was carried out using a $1 \mathrm{ml}$ sample with $1 \mathrm{ml} 6 \mathrm{~N} \mathrm{HCl}$, mixed well for sample separation; then the tube was sealed, digestion at $100^{\circ} \mathrm{C}$ took place for $22 \mathrm{~h}$, and then the filter was cooled and the filter changed in the amino acid analyzer, which performed by separating a hydrolysate standard, 4n mol/amino acid: concentration; LC 3000 standard program H1, readymadebuffers $\mathrm{H} 1$ (4-buffer system), column type $\mathrm{H} 125 \mathrm{X} 4 \mathrm{~mm}$, per-column type $60 \mathrm{X} 4 \mathrm{~mm}$.

\section{RESULTS AND DISCUSSION}

The aim of this work is the purification of certain commercially useful microbial products (pectinases enzymes), then evaluation of the fermented bagasse residuals as a fertilizer for the purpose of combatting soil desertification. Bagasse, the fibrous residue after sucrose extraction, consists of $46-49 \%$ cellulose, $25-27 \%$ hemicellulose and 20 $22 \%$ lignin [18]. While a portion of the fibre is marketed directly as combustible fuel or animal fodder, the bulk currently remains unused [19].The use of enzymes from thermophilic microbes offers important advantages over those of mesophiles in largescale biomass conversion processes [20].

Table 1.The optimum nutritional and environmental parameters controlling pectinases productivities by $T$. lanuginosus under SSF conditions.

\begin{tabular}{lc}
\hline Parameters & Total PNL and PL \\
\hline Temperature [21] & 55 \\
Bagasse conc. (g) & 4 \\
Inoculum size (disc) & 3 \\
Incubation period (day) & 5 \\
pH-factor & 6.2 \\
Flask volume (ml) & 2000 \\
Carbon sources & B+Ribose \\
Nitrogen sources & Pot. nitrate \\
Hormones & Cont. \\
Vitamins & Folic \\
Mineral salts & MS-1 \\
(U/ml) & $64.906 \pm 0.010$ \\
\hline
\end{tabular}

\section{Enzymes Production and Preparation of CFF}

Bagasse was evaluated as a sole carbon source for production of thermostable extracellular enzymes by Thermomonosporacurvata, an actinomycete which establishes itself as the dominant population during the high temperature composting of a variety of lignocellulosic material [22]. The solid-state fermentation (SSF) process is probably the largest enzyme producer worldwide [23]. In the present study, the fungal strain was allowed to grow on SCB as solid substrate, supplemented with MS under all the optimal static SSF conditions shown in Table 1. At the end of the incubation period, 1,200 $\mathrm{ml}$ of crude enzyme were extracted and collected separately. Centrifugation of the obtained extracts was done at $5,000 \mathrm{rpm}$ for $15 \mathrm{~min}$ at $10^{\circ} \mathrm{C}$, the precipitate was collected and 
tested for both enzyme activity, and protein content was determined and the corresponding specific activity (Sp. act.) was calculated, reaching $\left(113.661 \mathrm{Umg}^{-1}\right.$ ) at $55^{\circ} \mathrm{C}$ incubation temperature.

\section{Total PNL and PL Enzyme Purification}

The crude pectinase was purified by ammonium sulphate precipitation, dialysis and gel filtration chromatography [24]. Results represented graphically in Figure 1 indicated that the most active enzyme protein preparation was obtained with ammonium sulphate at a level of $60 \%$ for pectinases enzymes. The obtained precipitate was dissolved in $5 \mathrm{ml}$ of buffer used and subjected to a dialysation process against tap water to get rid of the excess of ammonium sulphate salt, and then tested for enzyme activity, and the protein content corresponding to specific activity was calculated. Total PNL and PL activity exhibited the maximum value at $(90.667 \pm 0.005 \mathrm{U} / \mathrm{ml})$ and protein content $(0.562$ $\mathrm{mg} / \mathrm{ml}$ ) corresponding to a sp. act.(161.329 $\left.\mathrm{Umg}^{-1}\right)$.Only $65.4 \mathrm{ml}$ was obtained at the end of the process of dialysation against tap water. The most active ammonium sulphate fractions previously obtained at $60 \%$ saturation $65.4 \mathrm{ml}$ were dialysed against sucrose crystals until a volume of $7.5 \mathrm{ml}$ was obtained and sp. act. was determined as $(986.810$ $\mathrm{Umg}^{-1}$ ), as shown in Table 2.

Table 2. Summary of purification steps of pectinases enzymes produced by $T$. lanuginosusat $55^{\circ} \mathrm{C}$.

\begin{tabular}{llcccccc}
\hline NO. & Purification step & $\begin{array}{c}\text { Volume } \\
(\mathrm{ml})\end{array}$ & $\begin{array}{c}\text { Enzyme } \\
\text { activity } \\
(\mathrm{U} / \mathrm{ml})\end{array}$ & $\begin{array}{c}\text { Protein } \\
\text { content } \\
(\mathrm{mg} / \mathrm{ml})\end{array}$ & $\begin{array}{c}\text { Specific } \\
\text { activity } \\
\left(\mathrm{Umg}^{-1}\right)\end{array}$ & $\begin{array}{c}\text { Protein } \\
\text { Fold }\end{array}$ & $\begin{array}{c}\text { Yield } \\
(\%)\end{array}$ \\
\hline 1. & $\mathrm{CFF}$ & 1200 & $50.352 \pm 0.003$ & 0.443 & 113.661 & 1.00 & 100 \\
2. & $\left(\mathrm{NH}_{4}\right)_{2} \mathrm{SO}_{4}(60 \%)$ & 100 & $90.667 \pm 0.005$ & 0.562 & 161.329 & 1.419 & 180 \\
3. & $\begin{array}{c}\text { Dialysis against } \\
\text { sucrose }\end{array}$ & 65.4 & $639.45 \pm 0.023$ & 0.648 & 986.81 & 8.682 & 1270 \\
4. & Sephadex G-200 & 5 & $2.258 \pm 0.001$ & 0.002 & 1129.00 & 9.933 & 4.484 \\
\hline
\end{tabular}

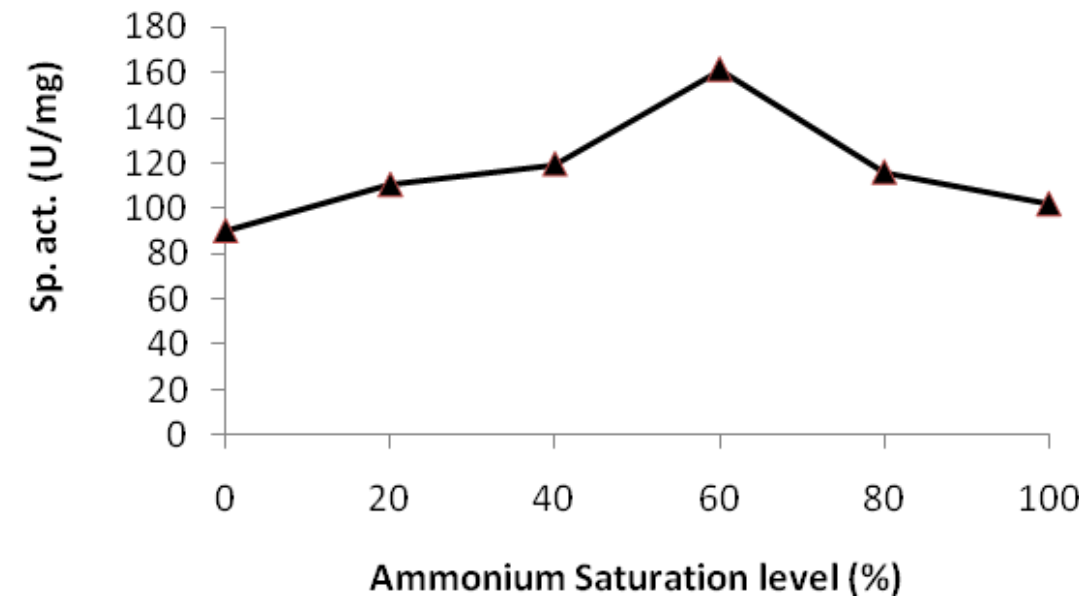

Figure 1. Ammonium sulphatefractionation levels. 


\section{Sephadex G-200 Gel Filtration Column}

Data represented in Figure 2 revealed that fifty fractions of total PNL and PL enzymes were collected; the fractions activities appeared from fraction 10 to 48 and the fraction number 43 reached the highest sp. act.of $\left(1129.000 \mathrm{Umg}^{-1}\right)$. Therefore, the general behaviour of the investigated purified enzyme showed two identical peaks, each representing one enzyme.According to Arijit et al. [24], the activity of the crude and purified pectinase was evaluated as $250 \mathrm{U} / \mathrm{land} 658 \mathrm{U} / \mathrm{l}$, respectively. The specific activity of the crude and purified pectinase wasrecorded as $744 \mathrm{Umg}^{-1}$ and $2610 \mathrm{Umg}^{-1}$, respectively. After column chromatography, a 3.5-fold increase in the specificactivity was noted.

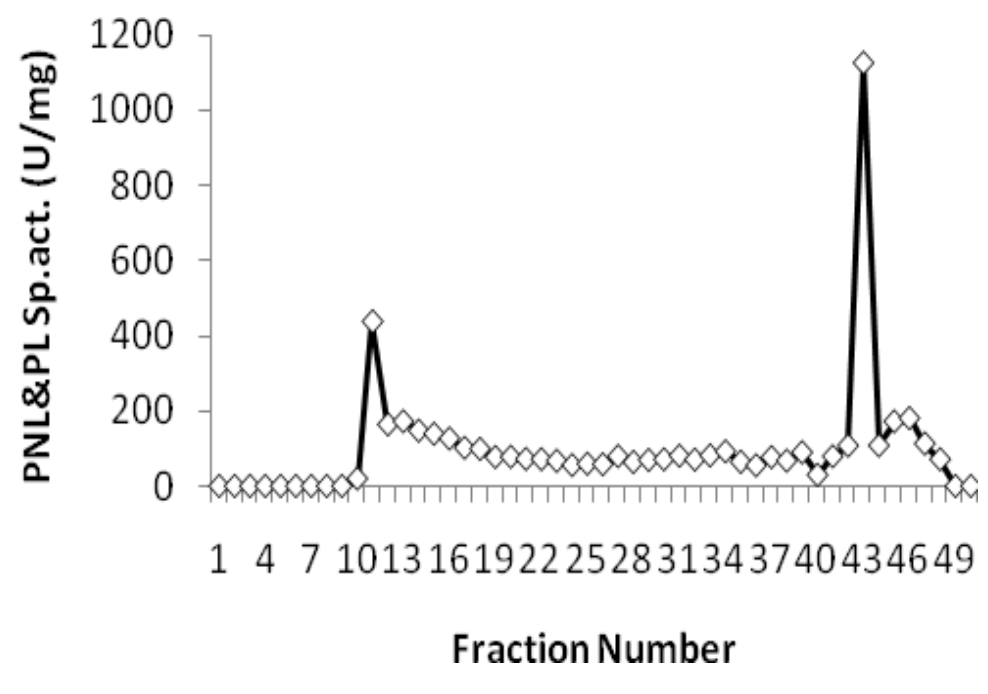

Figure 2. Fractions of Sephadex G-200 chromatography.

\section{Characterization of Purified Enzyme at $55^{\circ} \mathrm{C}$ under SSF Conditions}

Results represented in Figure 3 revealed that the highest total PNL and PL enzymes activity attained $(154.402 \pm 0.001 \mathrm{U} / \mathrm{ml})$ after the incubation time of the reaction mixture ranged from 10 to $20 \mathrm{~min}$. After this time, the enzyme activity decreased as the time increased. The $\mathrm{pH}$ of the fermentation medium plays a vital role in determining the level of metabolite synthesis. The stability of the microbial metabolite is also dependent on the hydrogen ion concentration of themedium [25]. Concerning $\mathrm{pH}$ values, as shown in Figure 4, the best $\mathrm{pH}$ value that fulfills the highest activity of total PNL and PL enzymes was $(148.603 \pm 0.004 \mathrm{U} / \mathrm{ml})$ at $\mathrm{pH}$ value 8.0 ; below and above this particular $\mathrm{pH}$ the enzyme activity gradually decreased. The initial medium $\mathrm{pH}$ of 8.5 supported maximum pectinase production (1340 U/l), as reported by Arijit et al. [24] . Data recorded in Figure 5 emphasized that the highest activity of total PNL and PL enzymes was increased at $300 \mu \mathrm{l}$ of enzyme concentration and attained $(152.395 \pm 0.001 \mathrm{U} / \mathrm{ml})$. The maximal activity of the enzymes was determined at $65^{\circ} \mathrm{C}$. PG was stable in the acidic to neutral $\mathrm{pH}$ range and at $60^{\circ} \mathrm{C}$ for $1 \mathrm{~h}$, whereas $\mathrm{PL}$ was stable at acidic $\mathrm{pH}$ and at $60^{\circ} \mathrm{C}$ for $5 \mathrm{~h}$ [26]. The enzyme was found to have a half-life of 5 hours at $42^{\circ} \mathrm{C}$ and 2 hours at $50^{\circ} \mathrm{C}$. In the present study, the data represented in Figure 6 shows that the maximum enzyme activity reached $(204.058 \pm 0.003 \mathrm{U} / \mathrm{ml})$ at $20^{\circ} \mathrm{C}$. Below and above 
this temperature, the enzyme activity decreased, although the enzyme exhibited an ability to work at an incubation temperature of $80^{\circ} \mathrm{C}$. The results presented in Figure 7 reveal that $0.2 \%$ of pectin concentration fulfilled the maximum activity $(61.783 \pm 0.002 \mathrm{U} / \mathrm{ml})$, while below and above this concentration the enzyme activity decreased gradually. A very similar study on pectinase production from a thermophilic Bacillus sp. reported maximum polygalacturonase synthesis $(39 \mathrm{U} / \mathrm{ml})$ inbroth containing $0.5 \%(\mathrm{w} / \mathrm{v})$ apple pectin and $0.3 \%(\mathrm{w} / \mathrm{v})$ cornsteep liquor with a $\mathrm{C} / \mathrm{N}$ ratio of 1.6 [27]. The optimization of substrate concentration demonstrated the highest pectinase activity of $1520 \mathrm{U} / \mathrm{l}$ from $0.3 \%(\mathrm{w} / \mathrm{v})$ pectin. Pectin percentages either lower or higher than $0.3 \%$ demonstrated lesser production of the enzyme [24].

\section{Biotechnological Application of Fermented Bagasse}

Data recorded in Table 3 shows the results when the fermented bagasse [16] obtained from the processes of pectinases enzymes purification at different concentrations was cultivated with Zea mays for 30 days, and indicates the growth of Zea mays on sandy soil as evidenced by data on root length (RL), shoot length (SL), fresh [28] and dry weights (DW), and determination of chorophyll (a), (b) and (a+b).It can be concluded thatthere is a specific concentration of the introduced organic manure (biofertilizer) which is responsible for plant growth and/or related parameters. These results are great values from the economic point of view. According to Wang et al. [29], application of sugar cane bagasse to areas planted with sugar cane increased root growth due to an increase in the amount of mycorrhizal hyphae. N-fixing bacteria, organic Pdecomposing and other bacteria in the rhizosphere all increased with bagasse application, as did soil enzyme activity and available N,P and K.

Table 3. Biotechnological application of fermented bagasse obtained from total PNL and PL enzyme production as organic manure in cultivation of Zea mays in sandy soil.

\begin{tabular}{cccccccc}
\hline $\begin{array}{c}\text { FB } \\
(\% \mathrm{w} / \mathrm{w})\end{array}$ & $\begin{array}{c}\text { RL } \\
(\%)\end{array}$ & $\begin{array}{c}\text { SL } \\
(\%)\end{array}$ & $\begin{array}{c}\text { FW } \\
(\%)\end{array}$ & $\begin{array}{c}\text { DW } \\
(\%)\end{array}$ & $\begin{array}{c}\text { Chlorophyll } \\
\mathrm{a}(\%)\end{array}$ & $\begin{array}{c}\text { Chlorophyll } \\
\mathrm{b}(\%)\end{array}$ & $\begin{array}{c}\text { Chlorophyll } \\
(\mathrm{a}+\mathrm{b})(\%)\end{array}$ \\
\hline Control & 100 & 100 & 100 & 100 & 100 & 100 & 100 \\
0.5 & 144.2 & 94.1 & 109.1 & 109.6 & 83.1 & 72.3 & 78.8 \\
1 & 171.4 & 96.9 & 89.7 & 85.5 & 110.5 & 99.1 & 106.0 \\
1.5 & 191.5 & 101.9 & 104.4 & 92.5 & 85.5 & 78.1 & 82.6 \\
2 & 191.1 & 111.7 & 112.7 & 89.8 & 74.8 & 68.7 & 72.4 \\
2.5 & 192.8 & 106.1 & 97.4 & 77.6 & 83.2 & 81.4 & 82.5 \\
3 & 183.9 & 102.6 & 104.9 & 79.6 & 124.4 & 118.4 & 122.0 \\
\hline
\end{tabular}

RL: root length; SL: shoot length; FW: fresh weight; DW: dry weight.

Among the most fascinating data in this work is that relating to the biotechnological application of fermented bagasse mixed with fungal biomass. Of special interest is the fact that the fermented bagasse successfully induced the growth of Zea plants, which may give an indication of the benefit of applying the present biofertilizer particularly in reclaimed sandy soils. Similar data, however, have been previously recorded by Moussa [30], who isolated pectinase(s) from marjoram fermentation under SSF and then applied the fermented material as a biofertilizer for Eruca sativa cultivation. Therefore, it can be concluded that the trend of using biofertilizers from the residual fermentation processes under SSF may find a good 
application in the field of soil reclamation and the production of economic crops without chemicals, which represents the main target of our research plan in the next years. A biotechnology for aerobic conversion of food waste into organic fertilizer under controlled aeration, stirring, $\mathrm{pH}$ and temperature at $55-65^{\circ} \mathrm{C}$ was reported by Stabnikova et al. [31].

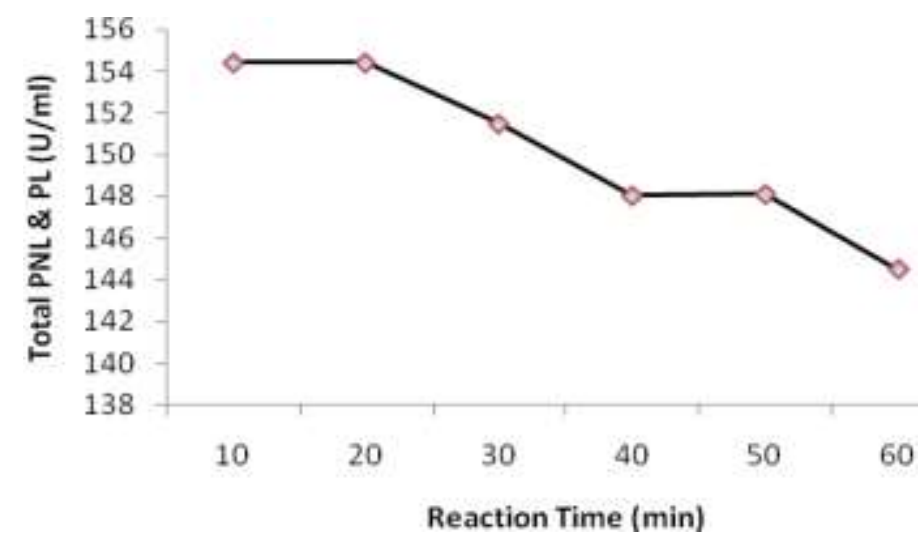

Figure 3. Effect of time progression.

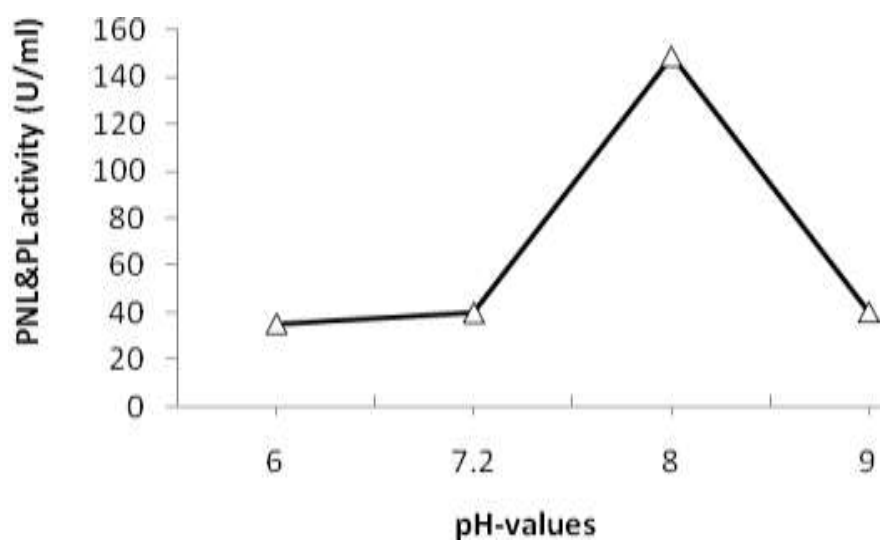

Figure 4. Relation of different $\mathrm{pH}$ values.

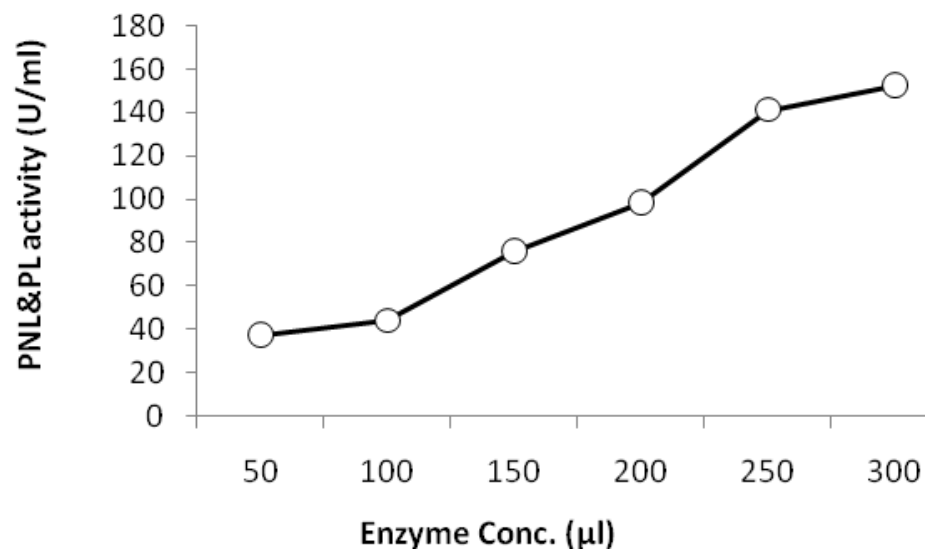

Figure 5. Effect of purified enzyme concentrations. 


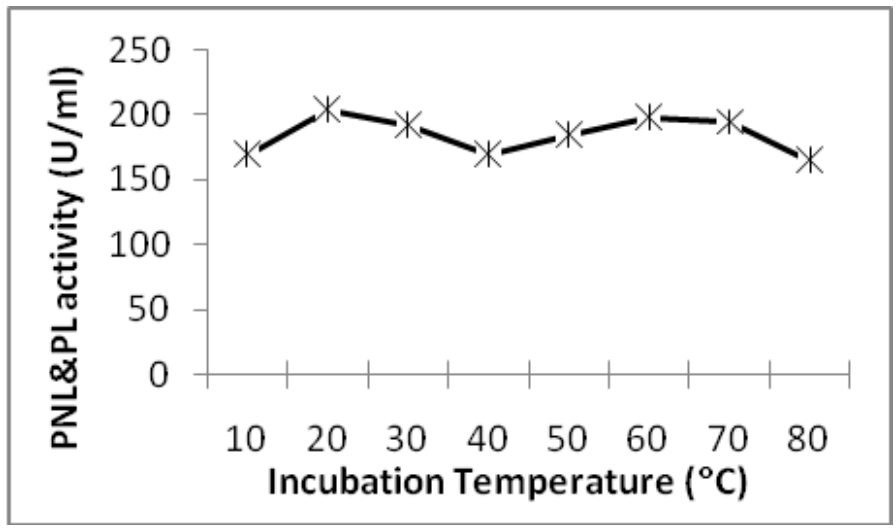

Figure 6. Effect of thermal stability.

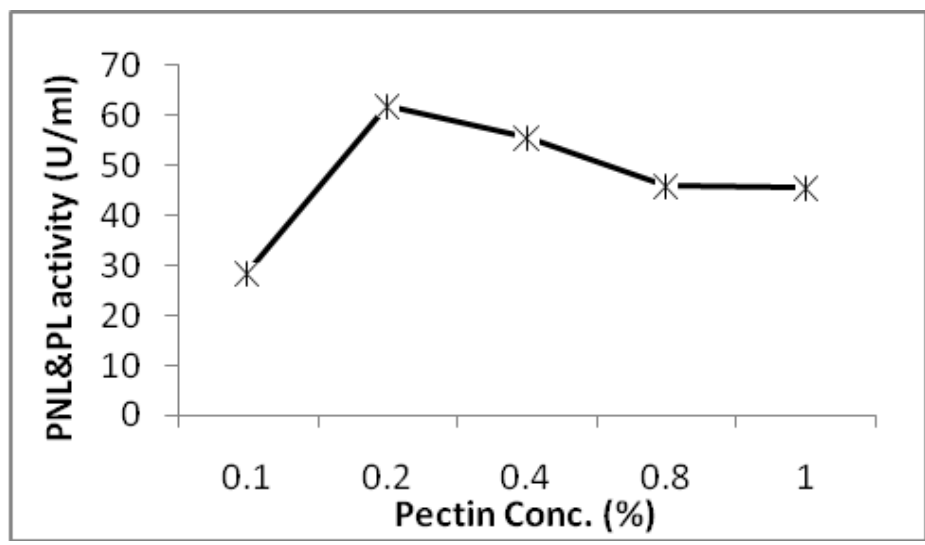

Figure 7. Effect of different substrate concentrations.

\section{Amino Acids Analytical Data of Purified Pectinases Enzymes}

As represented in Figure 8, it is obvious that 13 amino acids were detected, in addition to ammonium sulphate and glycine, which exhibited the highest value of 18.84\%.Interestingly, it can be seen that the amino acids analytical data of the investigated purified enzyme refers to the fact that total PNL and PL enzymes are glycine/histidine-containing enzymes. This means simply that the structure of the hydrolytic enzymes depends not only on the kind of producing strain but also on the substrate used for its production, as well as other factors controlling the nature of the fermentation process. The addition of $4 \%$ organic fertilizer to the subsoil increased the yield and growth of Ipomoea aquatica (Kang Kong) 1.5 to 2 times. The addition of phosphorus is required to enhance the positive effect of organic fertilizer on plant growth. Similar data were recorded by Frances et al. [32], who found that the amino acid content of the isoenzymes of endo-polygalacturonase was very similar toglycinecontaining enzymes. In contrast, Lin and Stutzenberger [33] reported that the amino acid composition indicated that about $24 \%$ of EG were aspartic and glutamic acids. Stutzenberger [34] noted that about $21 \%$ of the residues were aspartic and glutamic acids for PL enzyme. For comparative purposes, the data are expressed as molar percentages. Of the three enzymes, PG I was richest in aspartic acid, compared with PG II and PGIII. Similarly, glycine and alanine contents were higher in PG II and PG III. 


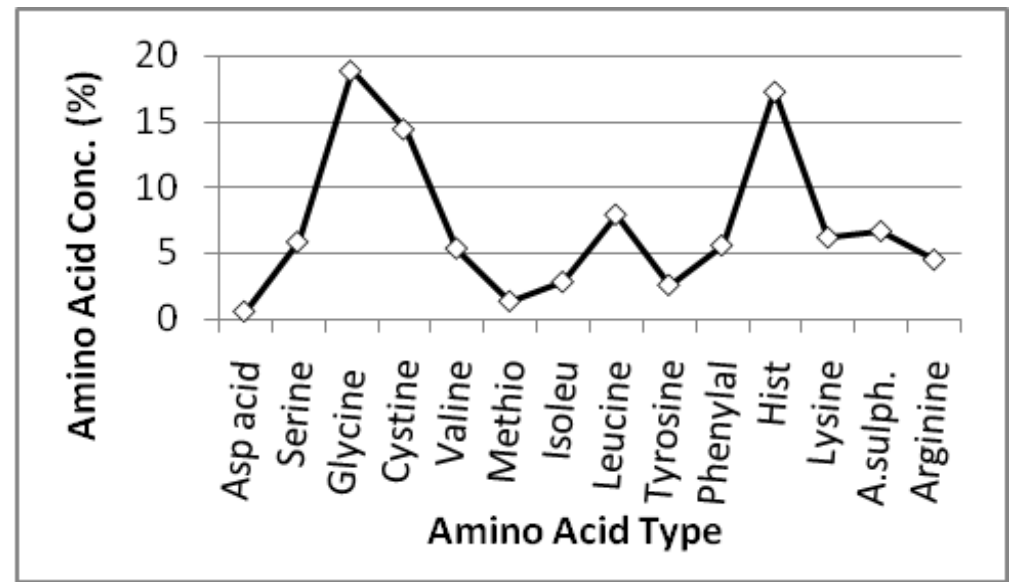

Figure 8.Amino acids analytical data of purified enzyme.

\section{CONCLUSIONS}

Thermomyceslanuginosus fungus possesses excellent enzymatic potential, besides its proven biodegradable properties at $55^{\circ} \mathrm{C}$ under SSF culture. The present study focused on purification of total PNL and PL enzymes from SCB as the sole carbon source and successfully applied the fermented bagasse residual as biofertilizer for the purpose of reclaimed sandy soil.

\section{ACKNOWLEDGEMENTS}

The authors are obliged to the Universiti Malaysia Pahang for providing laboratory facilities and financial assistance under project no. ERGS/RDU130611.

\section{REFERENCES}

[1] Balogun S. Potential of cassava liquid extract as a quenching medium for ferrous metal. Zaria, Nigeria: Ahmadu Bello University; 2009.

[2] Pandey A, Selvakumar P, Soccol CR, Nigam P. Solid state fermentation for the production of industrial enzymes. Current Science. 1999;77:149-62.

[3] Yadav S, Yadav PK, Yadav D, Yadav KDS. Pectin lyase: a review. Process Biochemistry. 2009;44:1-10.

[4] Murad H, Azzaz H. Microbial pectinases and ruminant nutrition. Research Journal of Microbiology. 2011;6:246-69.

[5] Dias MO, Ensinas AV, Nebra SA, Maciel Filho R, Rossell CE, Maciel MRW. Production of bioethanol and other bio-based materials from sugarcane bagasse: integration to conventional bioethanol production process. Chemical Engineering Research and Design. 2009;87:1206-16.

[6] Macrelli S, Mogensen J, Zacchi G. Techno-economic evaluation of 2nd generation bioethanol production from sugar cane bagasse and leaves integrated with the sugar-based ethanol process. Biotechnology for Biofuels. 2012;5:1-18.

[7] Davison BH, Drescher SR, Tuskan GA, Davis MF, Nghiem NP. Variation of S/G ratio and lignin content in a Populus family influences the release of xylose 
by dilute acid hydrolysis. Applied Biochemical Biotechnology. 2005;129132:427-35.

[8] Jørgensen H, Kristensen JB, Felby C. Enzymatic conversion of ignocellulose into fermentable sugars: challenges and opportunities. Biofuels, Bioproducts and Biorefining. 2007;1:119-34.

[9] Vargas Betancur GJ, Pereira Jr N. Sugar cane bagasse as feedstock for second generation ethanol production: Part I: Diluted acid pretreatment optimization. Electronic Journal of Biotechnology. 2010;13:10-1.

[10] Kumaran S, Sastuy CA, Vikineswary S. Lactase, cellulase, xylanase activities during growth of Pleurotussajor-cajuon sagohampas. World Journal of Microbiology and Biotechnology. 1997;13:43-9.

[11] Makky E. Comparison of Osmotic Stress on Growth and Pectinase Production by Aspergillus flavus in Liquid and Solid-State Cultures. Asian Journal of Experimental Sciences. 2009;23:19-26.

[12] Lowry OH, Rosebrough NJ, Farr AL, Randall RJ. Protein measurement with the Folin phenol reagent. The Journal of Biological Chemistry. 1951;193:265-75.

[13] Gomori G. Preparation of buffers for use in enzyme active studies.Method in Enzymol. I. London: Academic Press; 1955.

[14] Dixon M, Webb EC. Enzymes. 2nd ed. New York: Academic Press; 1964.

[15] Makky EA. Industrially important microbialby-products from bagasse fermentation technology and application of the fermented biomass in biofertilizers industry. Cairo, Egypt: Al-Azhar University; 2001.

[16] Borello G, Ferro S, Limone S, Ferro G, Bergamini P, Quagliotti F. The role of the moving ground for automotive wind tunnel testing on race cars. Training. 1999;2009:04-1.

[17] Vernon LP, Seely GR. The chlorophylls. New York and London: Academic Press; 1966.

[18] Espinosa JA, Battle E. Influence of new sugar cane varieties on the pulp and paper industry. Indian Pulp Paper. 1970;26:149-54.

[19] Roberto IC, Lacis LS, Barbosa MFS, deMancilha IM. Utilization of sugar cane bagasse HemicellulosicHydrolysateby Pichiastipitisfor the production of ethanol. Process Biochemistry. 1991;26:15-21.

[20] Margaritis A, Merchant R. CRC Crit. Rev. Biotechnology. 1986;4:327-67.

[21] CPG (Comp Performance Group). 2012.

[22] Stutzenberger FJ. Cellulase production by Thermomonospora curvata isolated from municipal solid waste compost. Applied Microbiology. 1971;22:147-52.

[23] Barbesgaard P. Industrial enzymes produced by members of the genus Aspergillus. In: Pateman JESaJA, editor. Genetics and Physiology of Aspergillus. London: Academic Press; 1977.

[24] Arijit D, Sourav B, Naimisha R, Rajan S. Improved production and purification of pectinase from Streptomyces sp. GHBA10 isolated from Valapattanam mangrove habitat, Kerala, India. International Research Journal of Biological Sciences. 2013;2:16-22.

[25] Kunamneni A, Permaul K, Singh S. Amylase production in solid state fermentation by the thermophilic fungus Thermomyces lanuginosus. Journal of bioscience and bioengineering. 2005;100:168-71.

[26] Martin N, Souza SRd, Silva Rd, Gomes E. Pectinase production by fungal strains in solid-state fermentation using agro-industrial bioproduct. Brazilian Archives of Biology and Technology. 2004;47:813-9. 
[27] Andrade MVVd, Delatorre AB, Ladeira SA, Martins MLL. Production and partial characterization of alkaline polygalacturonase secreted by thermophilic Bacillus sp. SMIA-2 under submerged culture using pectin and corn steep liquor. Food Science and Technology (Campinas). 2011;31:204-8.

[28] Stringer F, Clarke AE, Clarke JS. The spontaneous ignition of hydrocarbon fuels in a flowing system. Proceedings of the institution of mechanical engineers, conference proceedings: SAGE Publications; 1969. p. 212-25.

[29] Wang YZ, Pan TG, Ke YQ, Zherg SQ. Effect of applying the used bagasse substrate on sugar cane mycorrhizae, rhizospheremicrobes and soil fertility. Journal of Fujian Agricultural College. 1992;21:424-9.

[30] Moussa S. Use of solid statefermentation of agricultural wastes for enzyme production: Ain Shams Univ.; 1999.

[31] Stabnikova O, Ding HB, Tay JH, Wang JY. Biotechnology for aerobic conversion of food waste into organic fertilizer. Waste Management and Research. 2005;23:39-47.

[32] Frances MS, Morpeth FF, Pyle DL. Endopolygalaturonaseproduction from Kluyveromycesmarxianus. I. Resolution, purification and partial characterization of the enzyme. Enzyme and Microbial Technology. 1990;12:891-7.

[33] Lin SB, Stutzenberger F. Purification and characterization of the major $\beta-1,4-$ endoglucanase from Thermomonospora curvata. Journal of Applied Bacteriology. 1995;79:447-53.

[34] Stutzenberger FJ. Inducible thermoalkalophilicpolygalatouronatelyase from Thermomonosporafusca. Journal Bacteriology. 1987;169:2774-80. 